\title{
Mobilization of Non-conjugative Plasmids into Rhodopseudomonas sphaeroides
}

\author{
By V. V. ZINCHENKO, * M. M. BABYKIN AND S. V. SHESTAKOV \\ Department of Genetics, Biology Division, Moscow State University, Moscow 117234, USSR
}

(Received 15 February 1984)

\begin{abstract}
The non-conjugative plasmids pAS9, RSF1010, pBR325 and pML21 were mobilized from Escherichia coli into Rhodopseudomonas sphaeroides by conjugative plasmids of the P-1 incompatibility group or their derivatives. The transfer of plasmids pAS 9 and RSF 1010 was rec $A$-independent and both plasmids could be maintained in the autonomous state in $R$. sphaeroides cells. In contrast, the transfer of the plasmids pML21 and pBR325 based on the ColE 1 replicon was dependent on the $\operatorname{rec} A$ status of donor strains. Replication and maintenance of these plasmids occurred as a result of the production of cointegrates formed by recombination between the mobilized and mobilizing plasmids.
\end{abstract}

\section{INTRODUCTION}

The Gram-negative purple bacterium Rhodopseudomonas sphaeroides is an attractive model for investigating bacterial photosynthesis and nitrogen fixation. An efficient gene transfer system is essential for the genetic study of these processes in $R$. sphaeroides. One of the tools with most potential for the development of methods for complementation analysis and gene cloning is manipulation with plasmids which can be expressed in $R$. sphaeroides cells. A number of workers have reported that IncP-1 (Olsen \& Shipley, 1973; Sistrom, 1977; Tucker \& Pemberton, 1979 ) and IncW (Tucker \& Pemberton, 1979) group R plasmids are stably maintained in $R$. sphaeroides. Recently, the mobilization of chromosomal genes at high frequency promoted by plasmids RP1 ::Tn501 (Pemberton \& Bowen, 1981) and pAS8-121 rep : :Tn7 (Kameneva et al., 1982) have been demonstrated. Tucker \& Pemberton (1980) have reported the transformation of $R$. sphaeroides with DNA of the temperate bacteriophage R $\phi 6 \mathrm{P}$. The successful development of a transformation method for $R$. sphaeroides by plasmid DNA has been described by Fornary \& Kaplan (1982).

In this paper we describe studies of the mobilization of various non-conjugative plasmids, which are, or may be, used as recombinant DNA cloning vectors, from $E$. coli into $R$. sphaeroides.

\section{METHODS}

Bacterial strains and plasmids. The bacterial strains used were $R$. sphaeroides strain 2R (wild-type) and $E$. coli $\mathrm{K} 12$ strains $\mathrm{C} 600$ (thr leu thi lac tonA supE) and HB101 (leu pro lac gal rpsL thi hsdR hsdM recA56). All the strains were obtained from the collection of the Department of Genetics, Moscow State University. The plasmids utilized in this study are listed in Table 1.

Media. The media used were LB and minimal agar A (Miller, 1972) supplemented with $1 \mathrm{mg}$ nicotinic acid, $1 \mathrm{mg}$ biotin and $1 \mathrm{mg}$ thiamin per litre.

For the selection of antibiotic resistance a minimal medium was supplemented with various antibiotics at the following concentrations $\left(\mu \mathrm{g} \mathrm{ml}^{-1}\right)$ : kanamycin $(\mathrm{Km}, 100)$; tetracycline $(\mathrm{Tc}, 10)$; streptomycin $(\mathrm{Sm}, 100)$; and trimethoprim ( $\mathrm{Tp}, 50)$.

Drug resistance. Minimal inhibitory concentrations (MICs) of antibiotics were assayed from the curves of bacterial colony-forming ability on LB agar supplemented with different concentrations of antibiotics. MICs were determined as the minimal concentrations of antibiotics which decreased colony-forming ability by $50 \%$ after $48 \mathrm{~h}$ incubation. 
Table 1. Bacterial plasmids used

Plasmid Relevant properties*

pML21
pBR325
RSF1010
S-a
RP1
RP1-6Rep(ts12)::Tn7
RP1-6Rep(ts12)::Tn9
pAS8-101

pAS9
Icel $\mathrm{Km}$

Ap Tc Cm

IncQ $\mathrm{Sm} \mathrm{Su}$

IncW Km Su Sm Cm Tra

IncP-1 Ap Km Tc Tra

IncP-1 Km Tc Sm Tp Rep ts $T$ ra

IncP-1 Km Tc Cm Rep ts Tra

Icel Ap Sm Tp Tra

(derivative of RP4-ColE1 hybrid with insertion of

$\mathrm{Tn} 7$ into $\mathrm{Km}$ determinant)

Icel Ap Tc

(Deletion mutant of RP4-ColE1 hybrid)
Source or reference

Hershfeld et al. (1974)

Bolivar (1978)

Guerry et al. (1974)

Datta (1975)

A. I. Stepanov

G. B. Smirnov

G. B. Smirnov

A. I. Stepanov

Stepanov et al. (1976)

* Ap, ampicillin resistance; $\mathrm{Km}$, kanamycin resistance; Tc, tetracycline resistance; Sm, streptomycin resistance; $\mathrm{Su}$, resistance to sulphonamides; $\mathrm{Cm}$, chloramphenicol resistance; $\mathrm{Tp}$, trimethoprim resistance; Icel, immunity to colicin $\mathrm{E} 1$; Tra, self-mediated conjugation; Rep $_{\mathrm{ts}}$, temperature-sensitive replication; Inc, incompatibility group.

Table 2. MICs of antibiotics for $R^{-}$and $R^{+}$strains of $R$. sphaeroides

\begin{tabular}{|c|c|c|c|c|c|c|}
\hline \multirow[b]{2}{*}{ Strain } & \multicolumn{6}{|c|}{$\operatorname{MIC}\left(\mu \mathrm{g} \mathrm{ml}^{-1}\right)$} \\
\hline & $\mathrm{Km}$ & $\mathrm{Cm}$ & $\mathrm{Sm}$ & $\mathrm{Tp}$ & Tc & $\mathrm{Tc}^{*}$ \\
\hline Wild-type & 3 & 1 & 4 & 2 & 0.01 & ND \\
\hline RP1 & 400 & ND & 5 & 2 & $1-1.5$ & $10-15$ \\
\hline RP1-6Rep(ts12)::Tn7 & 400 & ND & 150 & 50 & $1-1.5$ & $10-15$ \\
\hline RP1-6Rep(ts12)::Tn 9 & 400 & 1 & ND & ND & $1-1.5$ & $10-15$ \\
\hline S-a & 50 & $i$ & 25 & ND & ND & $\mathrm{ND}$ \\
\hline
\end{tabular}

ND, Not determined.

* The cells were previously incubated on medium supplemented with $0 \cdot 3 \mu \mathrm{g}$ tetracycline $\mathrm{ml}^{-1}$ for $3 \mathrm{~h}$.

Mating procedure. For mobilization of non-conjugative plasmids triparental matings were used. Two RecA ${ }^{+}$or $R^{R e c A^{-}}$strains of $E$. coli were used as the donors: one of them contained the conjugative plasmid and the other the non-conjugative plasmid. Plate matings were performed by mixing $10^{9}$ cells each of overnight cultures of donor and recipient onto LB agar plates. The plates were incubated for $2.5-3 \mathrm{~h}$ at $35^{\circ} \mathrm{C}$. The cells were then washed from the agar surface and appropriate dilutions were plated onto selective medium to determine the viable count of the recipient population and the number of transconjugants formed. The transconjugant clones of $R$. sphaeroides were selected on minimal medium A supplemented with appropriate antibiotics. The colonies of $R$. sphaeroides were counted and analysed in 48-72 h. To induce resistance to tetracycline, $R$. sphaeroides cells or the conjugation mixtures were incubated in medium supplemented with $0.3 \mu \mathrm{g}$ tetracycline $\mathrm{ml}^{-1}$ for $3 \mathrm{~h}$.

\section{RESULTS}

\section{Expression of plasmid drug resistance genes in $R$. sphaeroides}

It has been shown previously that the majority of plasmid drug resistance genes are expressed in $R$. sphaeroides cells, the exception being the genes for resistance to the $\beta$-lactam antibiotics (Sistrom, 1977; Tucker \& Pemberton, 1979). In order to quantify the expression of plasmid drug resistance in $R$. sphaeroides $2 \mathrm{R}$ transconjugants, the MICs of several antibiotics were measured for the wild-type and for the strains carrying the plasmids S-a, RP1 and derivatives of RP1 carrying transposons $\operatorname{Tn} 7$ and $\operatorname{Tn} 9$. The results of these experiments are shown in Table 2. It was demonstrated that the resistance to chloramphenicol which is encoded by determinants of plasmid S-a and transposon Tn9 was not expressed in $R$. sphaeroides. The absence of resistance 
Table 3. Mobilization of non-conjugative plasmids in triparental matings from E. coli into $R$. sphaeroides $2 R$

$\begin{array}{lllr}\overbrace{\text { Strains }} & \text { Plasmids } & \text { Selection } & \begin{array}{c}\text { Mobilization } \\ \text { frequency }\end{array} \\ & \text { RP1 } & \text { Km } & 3.5 \times 10^{-3} \\ \text { RecA }^{+} & \text {RSF1010 } & \text { Sm } & 3 \times 10^{-3} \\ & \text { RP1 } & \text { Km } & 2 \times 10^{-3} \\ \text { RecA }^{-} & \text {RSF1010 } & \text { Sm } & 2 \times 10^{-3} \\ & \text { pAS8-101 } & \text { Sm } & 2 \times 10^{-3} \\ \text { RecA }^{+} & \text {pAS9 } & \text { Tc } & 3 \times 10^{-5} \\ & \text { pAS8-101 } & \text { Sm } & 1 \times 10^{-3} \\ \text { RecA }^{-} & \text {pAS9 } & \text { Tc } & 2.5 \times 10^{-5} \\ & \text { pAS8-101 } & \text { Sm } & 2 \times 10^{-3} \\ \text { RecA }^{+} & \text {pBR325 } & \text { Tc } & 1 \times 10^{-7} \\ & \text { pAS8-101 } & \text { Sm } & 1 \times 10^{-3} \\ \text { RecA }^{-} & \text {pBR325 } & \text { Tc } & <10^{-10} \\ & \text { pAS8-101 } & \text { Sm } & 2 \times 10^{-3} \\ \text { RecA }^{+} & \text {pML21 } & \text { Km } & 2.5 \times 10^{-6} \\ & \text { pAS8-101 } & \text { Sm } & 1 \times 10^{-3} \\ \text { RecA }^{-} & \text {pML21 } & \text { Km } & <10^{-10} \\ & \text { Each plasmid was in } E \text {. coli C600 or HB101 donor strain }\end{array}$

to this antibiotic is not due to plasmid segregation since all plasmids used in our experiments were stably maintained in $R$. sphaeroides under non-selective conditions and transferred all their markers in backcrosses with $E$. coli. The resistance to tetracycline encoded by RP1 was inducible (Table 2).

\section{Mobilization of the plasmids RSF 1010 and pAS9}

Non-conjugative plasmids RSF1010 and pAS9 were transmitted at high frequencies independently of the rec $A$ status of the donor strains (Table 3 ). The presence of these plasmids in $R$. sphaeroides transconjugants was confirmed by agarose gel electrophoresis of DNA extracts (data not shown). Previously Fornary \& Kaplan (1982) showed that RSF1010 is capable of stable maintenance in $R$. sphaeroides cells. Plasmid pAS9 is a deletion derivative of pAS8 (RP4-ColE1 hybrid) and can replicate in E. coli cells via RP4 or ColE1 replication systems (Sakanyan et al., 1977). The coordinates of deletion are 17.3-50.4 kb according to the RP4 map (Sakanyan et al., 1977) and pAS9, therefore, does not have oriT from RP4, which is located at $48 \mathrm{~kb}$ (Thomas et al., 1979). The mobilization of pAS9 is therefore rec $A$-independent and apparently initiated at the bom/nic site of ColE1, which is included in pAS9. According to Warren et al. (1978) mobilization of ColE1 by conjugative plasmids is initiated at the bom/nic site.

\section{Mobilization of the plasmids pBR325 and pML21}

The ColE1-like plasmid pBR325 and the mini-ColE1 derivative plasmid pML21 are well known cloning vectors for $E$. coli. Although the ColE1 replicon is not maintained in $R$. sphaeroides cells (Kameneva et al., 1982), the inheritance of these plasmids may be obtained by cointegration with a mobilizing plasmid. Under our experimental conditions the frequencies of mobilization of pML21 and pBR325 from $E$. coli $\operatorname{RecA}^{+}$strains were respectively three and four orders of magnitude lower than the transfer frequencies of conjugative mobilizing plasmids (Table 3). All transconjugants selected for markers of non-conjugative plasmids also carried all the markers from the mobilizing plasmids which are expressed in $R$. sphaeroides. When both donor strains were $\operatorname{RecA}^{-}$the mobilization of pML21 and pBR325 was not observed (Table 3). Agarose gel electrophoresis of plasmid DNA from transconjugants showed the presence of additional plasmid DNA bands with sizes greater than those corresponding to mobilizing plasmids (data not shown). Transconjugants in which pML21 or pBR325 existed in the autonomous state were never obtained (about 20 transconjugants were tested in each case). 


\section{DISCUSSION}

These results show that non-conjugative plasmids can be mobilized from $E$. coli into $R$. sphaeroides. This, as well as transformation, may be used to transfer plasmid vectors for cloning genes in $R$. sphaeroides cells. However, the absence of expression of genes determining resistance to chloramphenicol and $\beta$-lactam antibiotics in $R$. sphaeroides cells must be considered when choosing suitable cloning vectors. Mobilization allows the transfer of plasmids which are not able to exist in the autonomous state in $R$. sphaeroides through cointegration with a mobilizing plasmid. These cointegrates are formed by recA-dependent recombination (unpublished results) and the frequencies of mobilization of non-conjugative plasmids probably reflect the extent of homology of these plasmids with a mobilizing plasmid.

We would like to thank Dr A. I. Stepanov, Institute of Genetics and Selection of Industrial Microorganisms, Moscow, and Dr G. B. Smirnov, NF Gamaleya Research Institute for Epidemiology and Microbiology, Moscow, for the gift of plasmids.

\section{REFERENCES}

Bolivar, F. (1978). Construction and characterization of new cloning vehicles, III. Derivatives of plasmid pBR322 carrying unique EcoRI sites for selection of EcoRI generated recombinant molecules. Gene 4, 121-136.

DatTA, N. (1975). Epidemiology and classification of plasmids. In Microbiology-1974, pp. 9-15. Edited by D. Schlessinger. Washington, DC: American Society for Microbiology.

ForNaRY, C. S. \& KaPlan, S. (1982). Genetic transformation of Rhodopseudomonas sphaeroides by plasmid DNA. Journal of Bacteriology 152, 89-97.

Guerry, P., van Embden, J. \& Falkow, S. (1974). Molecular nature of two non-conjugative plasmids carrying drug resistance genes. Journal of Bacteriology 117, 619-630.

HeRSHFeld, V., BOyer, H., YANOFSKy, C., LOVett, M. \& Helinski, D. R. (1974). Plasmid ColE1 as a molecular vehicle for cloning and amplification of DNA. Proceedings of the National Academy of Sciences of the United States of America 71, 34553459.

Kameneva, S., Dubeikovsky, A., Polivzeva, T. \& Shestakov, S. (1982). Conjugation in Rhodopseudomonas sphaeroides $2 \mathrm{R}$ mediated by plasmids with transposable elements. In Abstracts of IV International Symposium on Photosynthetic Prokaryotes, p. D17. Bombannes, France.

Miller, J. H. (1972). Experiments in Molecular Genetics. New York: Cold Spring Harbor Laboratory.

OLSEN, R. R. \& Shipley, P. (1973). Host range and properties of the Pseudomonas aeruginosa $\mathbf{R}$ factor R1822. Journal of Bacteriology 113, 772-780.

Pemberton, J. B. \& Bowen, A. R. St G. (1981). High frequency chromosome transfer in Rhodopseudomonas sphaeroides promoted by the broad host-range plasmid RP1 carrying mercury transposon Tn501. Journal of Bacteriology 147, 110-117.

Sakanyan, V. A., Alikhanian, S. I., Yakubov, L. Z. \& STEPANOV, A. I. (1977). Isolation of non-transmissible deletion variants and the genetic map of plasmid pAS8 (RP4-ColE1). Genetika 13, 1778-1789 (in Russian).

Sistrom, W. R. (1977). Transfer of chromosomal genes mediated by plasmid R68.45 in Rhodopseudomonas sphaeroides. Journal of Bacteriology 131, 526-532.

Stepanov, A. I., Zimina, M. S., Khlebalina, O. I., Rabinovich, P. M., Beburov, M. Yu. \& Debabov, V. G. (1976). Transmissible hybrid plasmid RP4ColE1. Genetika 12, 162-164 (in Russian).

Thomas, C. M., Stalker, D., Guiney, D. \& Helinski, D. R. (1979). Essential regions for the replication and conjugal transfer of the broad host range plasmid RK2. In Plasmids of Medical, Environmental and Commercial Importance, pp. 375-385. Edited by K. N. Timmis \& A. Pühler. Amsterdam: Elsevier/ North Holland.

TuCker, W. T. \& Pemberton, J. M. (1979). Conjugation and chromosome transfer in Rhodopseudomonas sphaeroides mediated by $\mathrm{W}$ and $\mathrm{P}$ group plasmids. FEMS Microbiology Letters 5, 173-176.

TUCKer, W. T. \& PeMberton, J. M. (1980). Transformation of Rhodopseudomonas sphaeroides with DNA isolated from bacteriophage $\mathrm{R} \phi 6 \mathrm{P}$. Journal of Bacteriology 143, 43-49.

Warren, G. J., Twigg, A. J. \& Sherratt, D. J. (1978). ColEl plasmid mobility and relaxation complex. Nature, London 274, 259-261. 